\title{
Older and 'staying at home' during lockdown: informal care receipt during the COVID-19 pandemic amongst people aged 70 and over in the UK
}

\author{
Maria Evandrou ${ }^{1,2}$ Jane Falkingham ${ }^{1}$, Min Qin ${ }^{1}$ and Athina Vlachantoni ${ }^{1,2}$
}

\begin{abstract}
On 23 March 2020 the UK went into lockdown in an unprecedented step to attempt to limit the spread of coronavirus. Government advice at that time was that all older people aged 70 and over should stay at home and avoid any contact with non-household members. This study uses new data from the Understanding Society COVID 19 survey collected in April 2020, linked to Understanding Society Wave 9 data collected in 2018/19, in order to examine the extent of support received by individuals aged 70 and over in the first four weeks of lockdown from family, neighbours or friends not living in the same household, and how that support had changed prior to the outbreak of the coronavirus pandemic. The research distinguishes between different types of households as, given with guidance not to leave home and not to let others into the household, those older people living alone or living only with a partner also aged 70 and above are more likely to be particularly vulnerable. The results highlight both positive news alongside causes for concern. The receipt of assistance with Instrumental Activities of Daily Living (IADLs), especially shopping, has increased particularly among those living alone or with an older partner, reflecting the rise of volunteering and community action during this period. However, not all older people reported a rise, and the majority reported 'no change', in the support received. Moreover, amongst those older people reporting that they required support with at least one Activity of Daily Living (ADL) task prior to the pandemic, around one-quarter reported receiving no care from outside the household and one-in-ten of those with two or more ADL care needs reported receiving less help than previously. Although formal home care visits have continued during the pandemic to those who have been assessed by the local government to be in need, it is important to acknowledge that some older people risk not having the support they need.
\end{abstract}

Keywords: COVID-19, pandemic, social care, unmet needs, older people

\section{Funding}

This research was supported by the Economic and Social Research Council Centre for Population Change (grant number ES/K007394/1) at the University of Southampton.

\section{Competing interest}

Authors declare no competing interest.

\section{Authors affiliations}

${ }^{1}$ ESRC Centre for Population Change, University of Southampton, Southampton, UK

${ }^{2}$ Centre for Research on Ageing, University of Southampton, Southampton, UK 


\section{Older and 'staying at home' during lockdown: informal care receipt during the COVID-19 pandemic amongst people aged 70 and over in the UK}

\section{Background}

Since December 2019 a new coronavirus has emerged, resulting in a global pandemic. At the time of writing (June 2020), there have been more than 8.5 million acute respiratory syndrome (COVID-19) cases recorded, with 460,000 deaths in 188 countries (Johns Hopkins University, 2020). The epidemic has led to a range of public health actions being taken to control the spread of the virus (Bavel et al., 2020). Amongst these, the single most critical measure has been to foster a degree of physical distancing, reflecting the fact that the coronavirus spreads when an infected person coughs small droplets with the virus into the air. On 23rd March 2020 the UK went into lockdown in an unprecedented attempt to limit the spread of coronavirus, with the Government mandating all those who could, to work at home, closing all but essential shops and advising the population to stay at home and limit contact with other people outside their household. Individuals with specific medical conditions were identified as clinically extremely vulnerable and strongly advised to stay at home at all times and 'shield', avoiding all face-to-face contact. All older people aged 70 or older, regardless of medical conditions, were deemed to be clinically vulnerable and advised to stay at home as much as possible (Public Health England, 2020; Cabinet Office, 2020).

Lockdown has brought disruption to daily life for the whole population. Individuals aged 70 and over have, however, faced particular challenges in navigating how to secure food and other essentials and manage their health and care needs without leaving their home (AgeUK, 2020). In the UK, as in other countries, the support received by older individuals living in the community is provided from a range of sources, including informal sources such as one's family and friends, formal statutory sources such as the local council, or formal paid sources such as a privately paid carer. Historically, family members have provided the majority of informal care in later life, with much lower proportions of older people receiving regular help from friends or neighbours (Vlachantoni et al., 2015; Maplethorpe et al., 2015). During the COVID-19 pandemic, the printed press and media has cited many positive news stories highlighting how communities have come together to provide support to those shielding or isolating (e.g. BBC, 25 $5^{\text {th }}$ May 2020).

Meeting older people's needs for social care is crucial for maintaining older people's mental and physical health, wellbeing and dignity (Allen et al., 2014). Compared with older adults receiving adequate care, those reporting 'unmet needs' face greater challenges and vulnerabilities associated with their daily living activities, including a higher risk of falls, and a higher mortality rate (Komisar et al., 2005; Momtaz et al., 2012; He et al., 2015). In-depth interviews with individuals uncovered that unmet need for care is also associated with poor mental health and anxiety for some people, often associated with a sense of frustration and the daily struggle to meet their basic needs (Ipsos MORI, 2017). 
Whether older people with difficulties in daily living receive needed care has been found to be determined by the type and level of an individual's need, as well as their demographic, socio-economic and health status characteristics (Vlachantoni et al. 2011). In the UK context, according to Health Survey for England 2018 (Marcheselli and Ridout, 2019), 22 percent of men and 31 percent of women aged 65 and over needed help with at least one Activity of Daily Living $^{1}$ (ADL) and 20 percent of men and 32 percent of women respectively needed help with at least one Instrumental Activity of Daily Living (IADL). Many of these needs are however 'unmet', meaning that individuals do not receive any support associated with a particular need. From the same survey, it is reported that 19 percent of men and 28 percent of women aged 65 and over had some unmet need for help with at least one ADL, and 12 percent and 15 percent respectively had an unmet need for help with at least one IADL (ibid). The study found that the living arrangements of older people matter, with those living alone being more vulnerable to not receiving the care needed compared to cohabiting individuals (Löfqvist et al. 2016; Ipsos MORI, 2017).

Other research (Vlachantoni et al., 2015; Marcheselli and Ridout, 2019) highlights that receipt of support among older people increases with age. Care needs and receipt of help also vary according to household income, with those in the lowest income tertile both reporting the greatest need and the highest proportions receiving help. The number of IADLs an older person reports having difficulty with, followed by the number of ADLs, are the strongest determinants of receiving support from any source (Vlachantoni et al., 2015). Older people reporting poor health were most likely to report that they received care. Furthermore, different kinds of impediments in everyday life are associated with receiving support from different sources (Ibid).

It is important to note that social care needs and the likelihood of receiving assistance with such needs are not static but dynamic, and can shift as a result of the conditions through which the older person has lived, the challenges they have faced, and the resources available to them (Godfrey and Callaghan, 2000). The COVID-19 pandemic and the strict rules of staying at home are likely to have a significant impact on such dynamics, raising important policy concerns about the provision of social care to those who need it the most. This study aims to examine the extent of support received by individuals aged 70 and over from family, neighbours or friends not co-residing in the same household in the first four weeks of the COVID-19 pandemic lockdown, and how that support changed compared to prior to the outbreak of the coronavirus pandemic. The research distinguishes between different types of households, as those older people living alone, or living with a partner also aged 70 plus, might be thought to be particularly vulnerable, with the entire household having been advised to 'stay at home'.

\footnotetext{
${ }^{1}$ Activities of daily living (ADLs) include everyday tasks generally involving functional mobility and personal care, such as bathing, dressing, toileting, and eating. Instrumental activities of daily living (IADLs) include those life functions necessary for maintaining a person's immediate environment e.g. shopping, cooking, laundering, housecleaning, gardening.
} 


\section{Data and methods}

This study uses data drawn from the first wave of Understanding Society COVID-19 Study, conducted in April 2020 (University of Essex, 2020). Fieldwork was completed on $29^{\text {th }}$ April and thus covers the first month of lockdown. The data are linked to Wave 9 of Understanding Society conducted in 2018/19, providing information about the respondents prior to the outbreak of the pandemic. The analytical sample used here is restricted to all respondents aged 70 and over, constituting a sample size of 2,597. The characteristics of the sample are shown in Table $1^{2}$.

The key outcome variables include whether the respondent has received care in the last four weeks, as well as perceived changes in receiving such care as compared with the situation prior to the COVID-19 pandemic. The specific question wording is presented in the text box below.

Understanding Society: COVID-19 Study:

Thinking about the last 4 weeks, did you receive support from family, neighbours or friends who do not currently live in the same house/flat as you?

1. Yes

2. No

Thinking back to earlier this year, before the outbreak of the coronavirus pandemic. How has the help and support you receive from family, friends or neighbours who do not live in the same house/flat as you changed?

Please select all that apply.

1. There has been no change

2. I receive more help from some people who previously helped me

3. I receive less help from some people who previously helped me

4. I currently receive help from family, friends or neighbours who did not previously help me

5. Other

Source: University of Essex (2020).

Respondents were able to provide more than one answer to the question on how help and support has changed, as the answer codes are not mutually exclusive. The majority of respondents selected only one answer. However, amongst all the respondents aged 70 and over, 44 reported that they had received more help from some people who previously helped and also received support from family, friends or neighbours who did not previously help; and seven respondents reported receiving less help from some people who previously helped but had also received support from family, friends or neighbours who did not previously help.

\footnotetext{
${ }^{2}$ Women seem slightly underrepresented among the total population aged 70 and above in the Understanding Society: COVID-19 Study, compared to the Understanding Society Wave 9, where women were accounting for $54.4 \%$, and the mean age of both sexes was $77.6(\mathrm{SD}=6.2)$.
} 
Therefore, in the following analysis we have treated each specific change as an individual outcome variable; coded ' 1 ' if reporting this change and ' 0 ' otherwise.

A range of explanatory variables are of interest, capturing different dimensions of 'need'. The first of these is the type of household, with four categories: living in a single household, only with a partner aged 70 and over, only with a partner aged under 70 years, and living with an adult or others. Given the advice to 'stay at home', households containing only individuals aged 70 and over may be postulated to have a greater need for support for activities such as shopping.

In order to capture 'needs' unrelated to the pandemic itself and the associated lockdown, we have also included information on difficulties performing ADLs and IADLs as reported in Wave 9, collected prior to the COVID-19 pandemic. A total of 2,528 respondents aged 70 and over had full information in both Wave 9 and the COVID-19 module. An individual's difficulty in performing an activity reflected either only being able to perform that activity with help from someone else or not being able to manage at all. Twenty-two percent of respondents with complete information reported difficulty with at least one ADL. This included difficulty in managing stairs (3.6\%), getting around the house $(0.9 \%)$, getting in/out of bed $(0.9 \%)$, cutting one's toenails (17.8\%), bathing/showering (2.1\%), using the toilet (including getting up and down) (0.7\%), eating (including cutting up food) (0.8\%), washing one's face and hands (0.5\%), getting dressed and undressed (2.8\%), and taking the right amount of medicines at the right times (5.8\%). In terms of difficulties in performing IADLs, 17.7 percent of respondents aged 70 plus reported difficulties with at least one IADL. This included doing the shopping (9.6\%), housework or laundry (9.1\%), paperwork or pay bills (8.9\%), and walking down the road (5.0\%).

Other control variables include the respondents' demographic characteristics, for example their age, sex, and ethnicity, housing tenure and whether the respondent reports any current chronic health conditions.

\section{Results}

\section{Receipt of support from family, neighbours or friends in the past four weeks}

Amongst respondents aged 70 and over, two-thirds (66.7\%) reported that they had received support from family, neighbours or friends who did not live in the same house during the last 4 weeks (Table 2). A higher proportion of older women (70.1\%) than men (63.3\%) received care from outside the household. Not surprisingly there was also a gradient by age, with three-quarters of those in the oldest age group (aged 80 and over) reporting having received help and support in the last 4 weeks, but there was no significant difference by ethnicity.

The proportion of respondents receiving care varied according to the type of household $(\mathrm{p}<0.001)$, with four in five $(80.1 \%)$ of those older people living alone reporting having received support, and $70.0 \%$ among those living only with a partner aged 70 plus. This fell to just over half of those living with a partner younger than 70 years old (53.7\%) and those living with other (51.5\%). Although this paints a positive picture, it nevertheless illustrates 
that one in five people aged 70 and over living alone did not receive any support from informal sources (Figure 1).

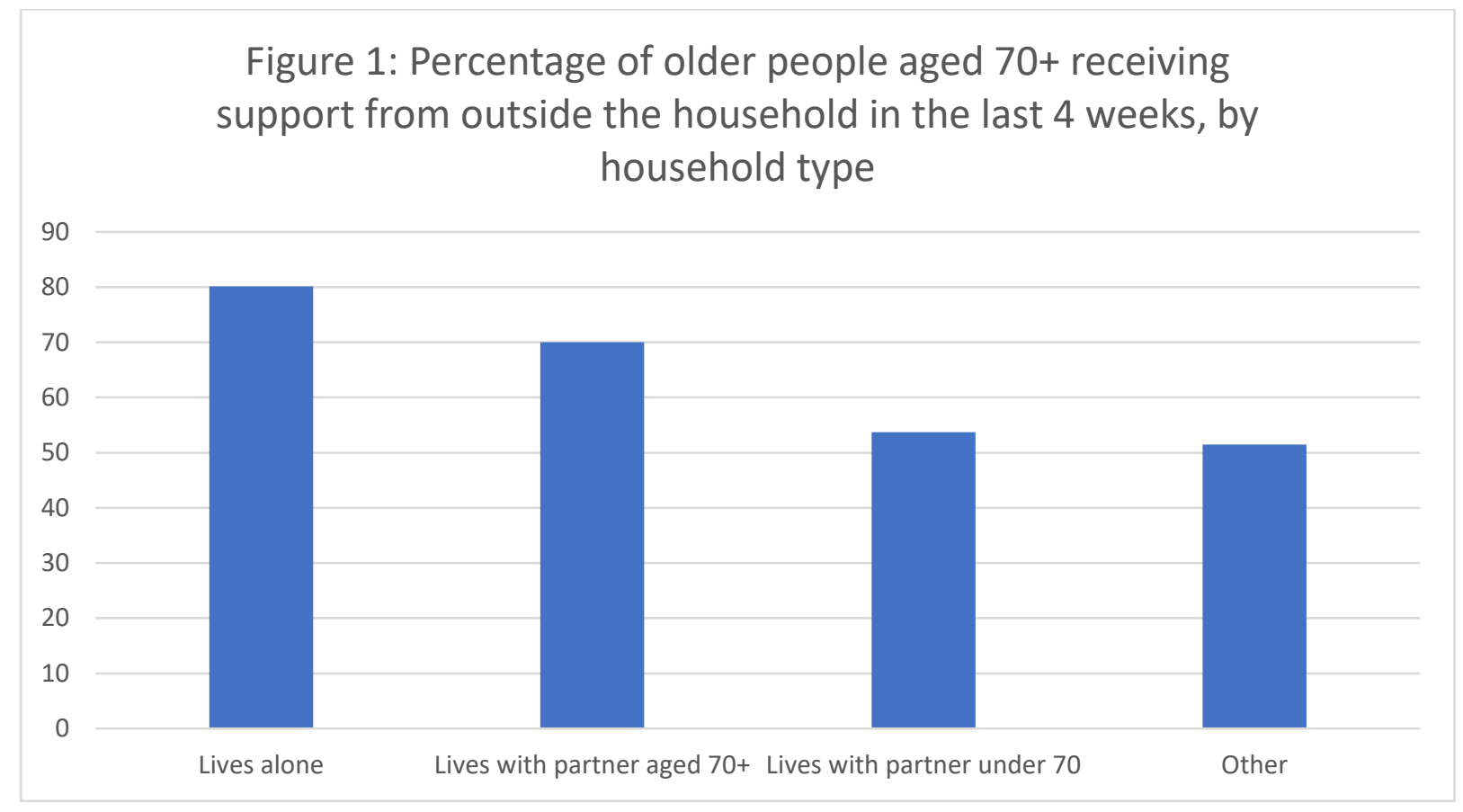

Turning to look at how this varied according to physical need, there is a clear association between difficulties in performing activities of daily living and receipt of support, with those respondents who reported difficulties in performing two or more ADLs or IADLs prior to the pandemic, being much more likely to receive help than those with no such difficulties (Figure 2).

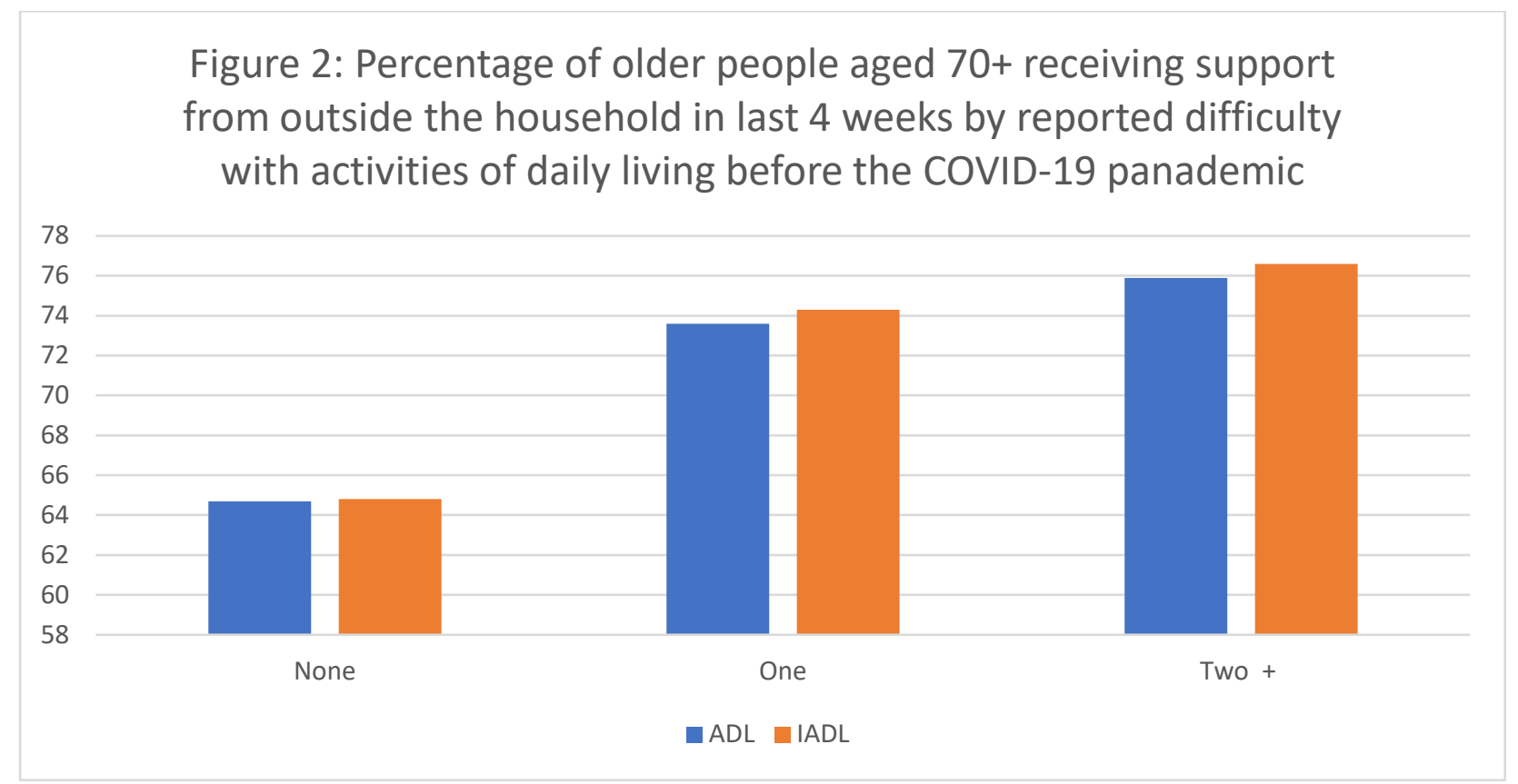


Table A1 in the appendix provides further insight, presenting information on the receipt of help and support by reporting of difficulty with ADLs and IADLs within each household type. Amongst those older people aged 70 and over reporting difficulty with two or more IADLs, $94.4 \%$ of those living alone received support from outside the household, compared to $88 \%$ of those living with a partner also aged 70 and over (who technically should also be shielding), $69.2 \%$ of those living with a partner aged under 70 and just $44.4 \%$ of those living with other adults. Thus, it appears that those 'most in need', i.e. living alone and with 'need', were most likely to receive help with instrumental activities of daily living. However, $17 \%$ of those older people living alone who reported two or more difficulties with personal care tasks, i.e. with ADLs, did not receive any external informal assistance, pointing to potential unmet need for such tasks.

This is borne out by examining the type of care provided. Of those 1,685 respondents receiving support from family, friends and neighbours outside the household, assistance with shopping (including going to the shop or ordering an online delivery) was by far the most common task, experienced by over nine out of ten older people (91.2\%). This contrasts sharply with the pre-COVID situation where just $9 \%$ of the respondents reported that they needed assistance with this IADL. Around one-in-ten older people receiving support reported assistance with online or internet access (10.6\%), cooked meals (9.6\%), decorating, gardening or house repairs (9.0\%). Many fewer respondents reported receiving support for more personal tasks such as washing, ironing or cleaning (6.8\%) and dealing with personal affairs, such as paying bills and writing letters (4.5\%). Just $1.1 \%$ reported receiving help with basic personal needs like dressing, eating or bathing; tasks which involve individuals accessing the respondents' home.

Some types of help received during the pandemic differed according to the type of household, with those living alone being more likely than the average to report having received cooked meals (15.6\%), support with decorating, gardening or house repairs (13.9\%), assistance with online or internet access (15.4\%), and support for dealing with personal affairs (7.5\%).

The main sources of care were adult children, including in-laws (67.7\%), neighbours (37.0\%), friends (20.1\%), non-co-residential spouse or partner (8.4\%) and siblings (7.6\%). The distribution of caregivers was different according to the type of household. The proportion of adult children, including in-laws, reported as the caregivers was the highest among older people living only with a partner aged 70 and over (72.3\%) and the lowest among older people living alone (60.6\%) (see appendix Table A2). There was no difference in the proportion receiving care from neighbours and friends between different household types.

\section{Changes in receipt of care from family, neighbours or friends since the COVID-19 pandemic}

When asked to compare their current help and support with that received prior to the outbreak of the coronavirus pandemic, just over a quarter of respondents aged 70 and over (27\%) reported receiving help from family, friends or neighbours who did not previously provide help and just under a fifth (17.7\%) reported receiving more help from some people who 
previously helped; only a small minority (4.1\%) reported receiving less help; and around a half (51\%) reported no change in care receipt (Table 2). Once more, there were significant differences by household type.

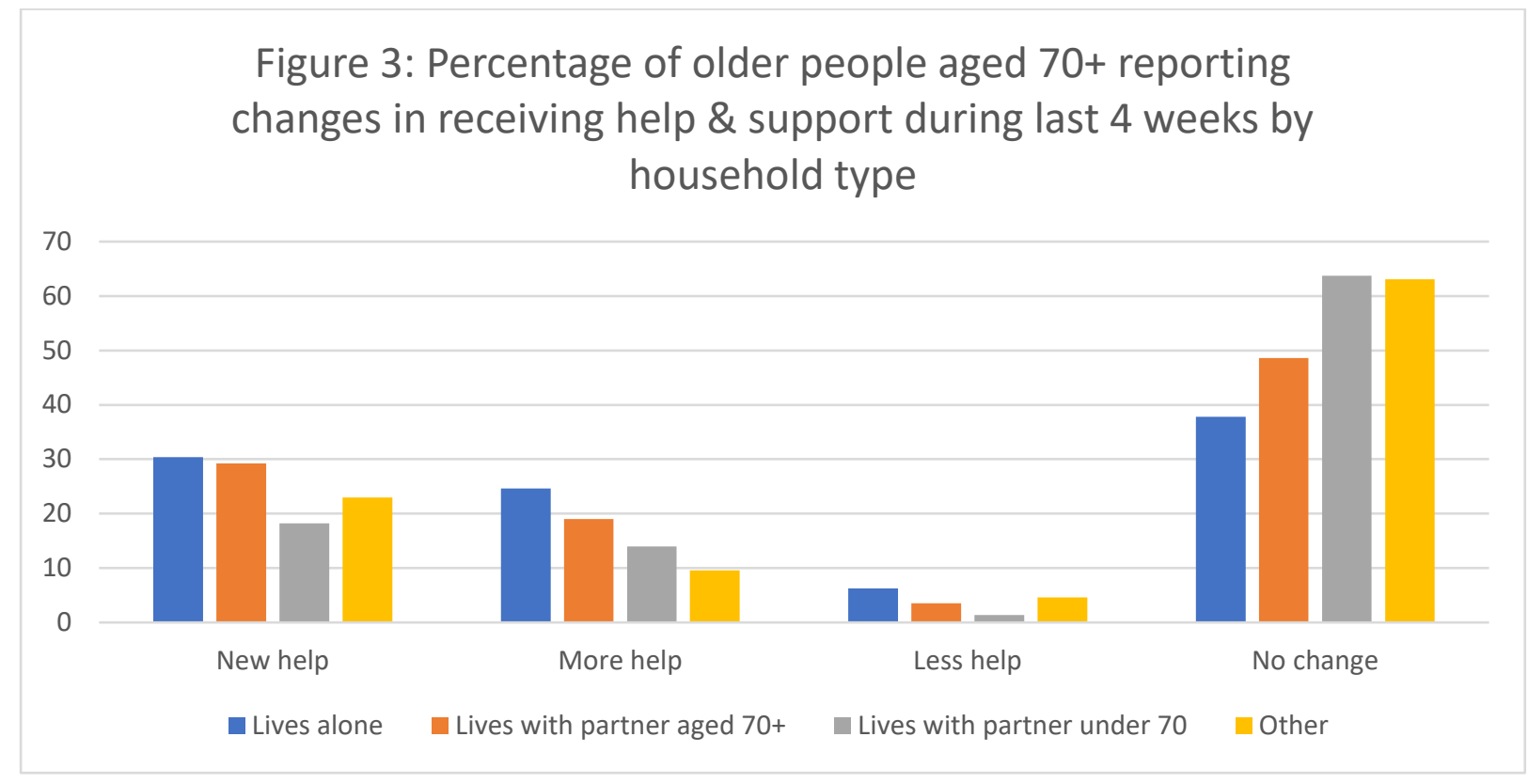

Older people living alone or only with a partner aged 70 and over were more likely to report receiving support from family, friends or neighbours who did not previously help, or receiving more help from someone people who previously helped. It should also be noted, however, that older people living alone were also most likely to report receiving less help than that of those from other households. More worryingly, one-in-ten of those who reported two or more difficulties in performing ADLs prior to the pandemic reported receiving less help.

The results discussed so far have explored associations between characteristics individually. Results from the multivariate analysis (Table 3) confirm that individuals living alone or only with a partner aged 70 and over, were more likely to receive care from outside the house, as were those aged $80+$, with at least one chronic condition, and women. Living alone and having at least one chronic condition was also associated with being more likely to receive more help from some people who previously helped. Household type was not however statistically significantly associated with the receipt of help from a new source.

Interestingly the only group which was likely to receive less help were those older people who reported difficulty with two or more IADLs prior to the pandemic. There was also an elevated odds ratio of receiving less help amongst those older people with two or more difficulties in performing ADLs, although this was not statistically significant due to a low sample size. Nevertheless, it is indicative that there may be a small but vulnerable group of incapacitated older people whose needs for daily living are not being met during the pandemic. Amongst the 511 respondents who had reported difficulty in performing at least 
one ADL prior to the pandemic, just 7 respondents reported receiving help with basic personal needs like dressing, eating or bathing during the first 4 weeks of the lockdown.

\section{Discussion and Conclusion}

This paper provides the first insight into the receipt of help and support amongst older people aged 70 and over during the first 4 weeks of the COVID-19 pandemic lockdown when this group had been explicitly advised to stay at home and minimise contact with others. We contrast elderly couples where both are over 70 and compare these with couples where one is aged under 70 years and thus not classified as clinically vulnerable unless they have other underlying conditions. This help us to understand how 'extreme social distancing' has impacted upon the health and well-being of older people.

The good news is that these research results indicate that the majority of older people received support from the broad community. Apart from families living outside the house, neighbours and friends have played an essential role in providing support to this vulnerable group. Since the pandemic, a significant proportion of older people received an increased level of help from existing caregivers or received support from new caregivers. This was especially the case amongst those living alone or with a partner aged 70 and over. However, there is also evidence that older people with difficulties in performing key activities of daily living, faced a higher risk of receiving less care and support during the lockdown, raising the spectre that some older people are not receiving adequate social care.

One of the features of the Government advice to tackle COVID-19 has been the use of the age cut-off of 70 years and over to define those who may be clinically vulnerable and therefore need to take extra precautions including 'shielding' at home. For those who live alone, this has presented additional challenges around undertaking IADLs, such as shopping and taking physical exercise. The research here indicates that assistance with such tasks seems to have increased, reflecting the rise of volunteering and community action during this period (Booth, 2020; Local Government Association, 2020; Van Bavel et al. 2020), although not all older people living alone reported a rise and the majority reported 'no change'. However, the fact that this group have been asked to isolate also means that the need for help with basic personal needs is more likely to go unmet as the advice has been not to allow people from outside the household into your home. Our results seem to confirm this. The social policy response to the COVID-19 pandemic needs to pay explicit attention to older people who have difficulties with multiple IADL and ADLs in order to ensure that their needs are being met. Previous research has shown that statutory social services are being increasingly concentrated on those with the highest level of need (Vlachantoni, 2019). There is a danger that during the pandemic those older people with more moderate needs may slip under the radar of the formal safety net, and with informal carers unable to fulfil these needs, unmet need may rise, resulting in a heightened risk of falls and other unanticipated visits to hospital A\&E.

This paper provides an important first contribution to our understanding of the dynamic of social care receipt from the community during the COVID-19 pandemic amongst individuals with major vulnerabilities. The authors acknowledge that this paper has the following 
limitations which should be taken into account. Firstly, given the data constraint, the need for care associated with ADLs and IADLs is not measured contemporaneously but rather inferred from previous reports. It may be that someone who reported difficulty with an ADL in 2019 had recovered, whilst another older person who previously did not report a difficulty, now does. It may be the case that some individuals not receiving care do so because they no longer require it. It would strengthen the understanding of the extent of unmet need if future rounds of the COVID-19 module study collected information on ADLs and IADLs. Secondly, it is not possible to link the type of carer, for example the adult child or neighbour etc with the provision of assistance with specific tasks. Previous research has shown that formal support tends to be used for more basic and personal tasks, while informal support tends to be used for more instrumental tasks (Vlachantoni et al., 2015). Including such information would help us better understand 'who helps with what tasks' and thus which care needs remain unmet and how these can be best addressed - informing policy debate. 


\section{Reference}

Allen, S.M., Piette, E., and Mor, V. (2014) The adverse consequences of unmet need among older persons living in the community: dual-eligible versus medicare-only beneficiaries. Journals of Gerontology, Series B: Psychological Sciences and Social Sciences, 69, 7, S51S58.

AgeUK. (2020) Older people's lives during the pandemic.

https://www.ageuk.org.uk/globalassets/age-uk/documents/reports-and-publications/reportsand-briefings/health--wellbeing/behind-the-headlines/behind_the_headlines_coronavirus.pdf (16 May 2020)

BBC (25 ${ }^{\text {th }}$ May) 'How lockdown brought a village closer together'. https://www.bbc.co.uk/news/av/uk-52789073/coronavirus-how-lockdown-brought-a-villagecloser-together

Booth, R. (2020) Community aid groups set up across UK amid coronavirus crisis. The Guardian. https://www.theguardian.com/society/2020/mar/16/ community-aid-groups-set-up-across-uk-amid-coronavirus-crisis (16 May 2020)

Cabinet Office. (2020) Coronavirus (COVID-19) guidance: Staying alert and safe (social distancing). https://www.gov.uk/government/publications/staying-alert-and-safe-socialdistancing/staying-alert-and-safe-social-distancing\#clinically-vulnerable-people (16 May 2020).g

Godfrey, M. and Callaghan, G. (2000) Exploring unmet need. The challenge of a user-centred response. Joseph Rowntree Foundation Report.

He, S., Craig, B. A., Xu, H., Covinsky, K. E., Stallard, E., Thomas III, J., Hass, Z. and Sands, L. P. (2015) Unmet need for ADL assistance is associated with mortality among older adults with mild disability. Journals of Gerontology: Medical Sciences, 70, 9, 1128-1132.

Ipsos MORI. (2017) Unmet need for care. Ipsos MORI Report 15-042098-01.

Local Government Association. (2020) Guidance of protecting vulnerable people during the COVID-19 outbreak. https://www.local.gov.uk/protecting-vulnerable-people-during-covid19-outbreak (12 June 2020)

Johns Hopkins University. (2020) COVID-19 Dashboard by the Centre for Systems Science and Engineering (CSSE) at Johns Hopkins University https://coronavirus.jhu.edu/map.html. (12 June 2020)

Komisar, H.L., Judith, F. and Judith, K. (2005) Unmet Long-term care needs: An analysis of medicare-medicaid dual eligibles. Inquiry, 42, 2, 171-82.

Löfqvist, C., Slaug, B., Ekström, H., Kylberg, M. and Haak, M. (2016) Use, non-use and perceived unmet needs of assistive technology among Swedish people in the third age. Disability and Rehabilitation: Assistive Technology, 11, 3, 195-201.

Marcheselli, F. and Ridout, K. (2019) Health Survey for England 2018 Social care for older adults. Health and Social Care Information Centre report. 
Maplethorpe, N., Darton, R. and Wittenberg, R. (2015) Social care: Need for and receipt of help. Health Survey for England 2014. Health and Social Care Information Centre. http://healthsurvey.hscic.gov.uk/media/33548/HSE2014-Ch5-Social-care-needand-receipt.pdf (8 June 2020).

Momtaz, Y. A., Hamid, T. A., Ibrahim, R. (2012) Unmet needs among disabled elderly Malaysians. Social Science \& Medicine, 75, 859-863.

Public Health England. (2020) Guidance on shielding and protecting people who are clinically extremely vulnerable from COVID-19.

https://www.gov.uk/government/publications/guidance-on-shielding-and-protectingextremely-vulnerable-persons-from-covid-19/guidance-on-shielding-and-protectingextremely-vulnerable-persons-from-covid-19. (8 June 2020)

University of Essex, Institute for Social and Economic Research. (2020) Understanding Society: COVID-19 Study, 2020. [data collection]. UK Data Service. SN: 8644, http://doi.org/10.5255/UKDA-SN-8644-1.

Van Bavel, J. J., Baicker, K., Boggio, P. S. et al. (2020) Using social and behavioural science to support COVID-19 pandemic response. Nature Human Behaviour, 4: 460-471.

Vlachantoni, A. (2019) Unmet need for social care among older people. Ageing \& Society, 39(4), 657-684.

Vlachantoni, A., Shaw, R., Willis, R., Evandrou, M., Falkingham, J. and Luff, R. (2011)

Measuring unmet need for social care amongst older people. Population Trends, 145, 60-76.

Vlachantoni, A., Shaw, R. J., Evandrou M. and Falkingham, J. (2015) The determinants of receiving social care in later life in England. Ageing \& Society, 35: 321-345. 
Table 1. Sample characteristics

\begin{tabular}{|c|c|c|}
\hline & \% (applied sampling weight) & $\begin{array}{l}\text { Number of respondents } \\
\text { (unweighted) }\end{array}$ \\
\hline Total & 100.0 & 2597 \\
\hline \multicolumn{3}{|l|}{ Age group } \\
\hline $70-74$ & 48.2 & 1393 \\
\hline 75-79 & 29.1 & 747 \\
\hline $80+$ & 22.7 & 457 \\
\hline \multicolumn{3}{|l|}{ Sex } \\
\hline Men & 50.5 & 1303 \\
\hline Women & 49.5 & 1294 \\
\hline \multicolumn{3}{|l|}{ Ethnicity } \\
\hline BESWN & 94.8 & 2425 \\
\hline Other ethnic groups & 5.2 & 172 \\
\hline \multicolumn{3}{|l|}{ Type of household } \\
\hline Single household & 22.8 & 526 \\
\hline With a partner aged 70+ & 44.9 & 1229 \\
\hline With a partner aged younger than 70 & 11.4 & 321 \\
\hline With an adult or others & 20.9 & 521 \\
\hline \multicolumn{3}{|l|}{ Housing tenure } \\
\hline Owned outright & 79.2 & 2145 \\
\hline Owned with mortgage & 6.4 & 172 \\
\hline Rent & 14.4 & 280 \\
\hline \multicolumn{3}{|c|}{ Whether had at least one chronic condition } \\
\hline No & 23.2 & 625 \\
\hline Yes & 76.8 & 1972 \\
\hline \multirow{2}{*}{\multicolumn{3}{|c|}{$\begin{array}{l}\text { Difficulty with number of ADLs before the } \\
\text { COVID-19 pandemic }\end{array}$}} \\
\hline & & \\
\hline None & 77.5 & 2017 \\
\hline One & 17.5 & 421 \\
\hline Two more & 4.4 & 90 \\
\hline Missing & 0.6 & 69 \\
\hline \multicolumn{3}{|c|}{$\begin{array}{l}\text { Difficulty with number of IADLs before } \\
\text { the COVID-19 pandemic }\end{array}$} \\
\hline None & 81.7 & 2108 \\
\hline One & 9.5 & 232 \\
\hline Two more & 8.1 & 188 \\
\hline Missing & 0.6 & 69 \\
\hline
\end{tabular}

Source: authors' analysis, Understanding Society: COVID-19 Study, 2020.

BESWN means British/English/Scottish/Welsh/Northern Irish (white) 
Table 2. Receiving care in the last 4 weeks and perceived changes in receiving such care since the COVID-19 pandemic according to the respondents' characteristics

\begin{tabular}{|c|c|c|c|c|c|}
\hline & \multirow{2}{*}{$\begin{array}{l}\text { Receiving } \\
\text { care from } \\
\text { outside the } \\
\text { house }\end{array}$} & \multicolumn{4}{|c|}{$\begin{array}{l}\text { Perceived changes in receiving care from outside the household after the } \\
\text { pandemic }\end{array}$} \\
\hline & & $\begin{array}{l}\text { Receiving more } \\
\text { help from some } \\
\text { people who } \\
\text { previously helped }\end{array}$ & $\begin{array}{l}\text { Receiving less } \\
\text { help from some } \\
\text { people who } \\
\text { previously } \\
\text { helped }\end{array}$ & $\begin{array}{l}\text { Receiving help from } \\
\text { family, friends or } \\
\text { neighbours who did } \\
\text { not previously help }\end{array}$ & $\begin{array}{l}\text { No } \\
\text { change }\end{array}$ \\
\hline Total & 66.7 & 17.7 & 4.1 & 26.9 & 50.9 \\
\hline Age group & $* * *$ & $* *$ & NS & NS & $* *$ \\
\hline $70-74$ & 60.8 & 14.8 & 4.1 & 25.4 & 54.7 \\
\hline $75-79$ & 69.1 & 19.5 & 3.5 & 26.9 & 49.2 \\
\hline $80+$ & 76.0 & 21.7 & 5.1 & 30.5 & 45.2 \\
\hline Sex & $* *$ & $* *$ & NS & $*$ & $* * *$ \\
\hline Men & 63.3 & 15.4 & 3.8 & 24.7 & 56.1 \\
\hline Women & 70.1 & 20.1 & 4.5 & 29.2 & 45.8 \\
\hline Ethnicity & NS & NS & NS & NS & NS \\
\hline BESWN & 66.7 & 17.8 & 4.0 & 27.2 & 50.7 \\
\hline Other ethnic groups & 65.3 & 17.3 & 7.1 & 22.2 & 56.1 \\
\hline Type of household & $* * *$ & $* * *$ & $*$ & $* *$ & $* * *$ \\
\hline Single household & 80.1 & 24.6 & 6.3 & 30.4 & 37.8 \\
\hline $\begin{array}{l}\text { With a partner aged } \\
70+\end{array}$ & 70.0 & 19.0 & 3.5 & 29.2 & 48.6 \\
\hline $\begin{array}{l}\text { With a partner aged } \\
\text { younger than } 70\end{array}$ & 53.7 & 14.0 & 1.4 & 18.2 & 63.7 \\
\hline $\begin{array}{l}\text { With an adult or } \\
\text { others }\end{array}$ & 51.5 & 9.6 & 4.6 & 23.0 & 63.1 \\
\hline Housing tenure & NS & $*$ & NS & $*$ & NS \\
\hline Owned outright & 66.6 & 18.9 & 3.7 & 27.1 & 50.4 \\
\hline Owned with mortgage & 58.7 & 13.9 & 2.5 & 20.7 & 60.3 \\
\hline Rent & 70.5 & 12.9 & 7.4 & 28.8 & 49.8 \\
\hline $\begin{array}{l}\text { Whether had at least } \\
\text { one chronic } \\
\text { condition }\end{array}$ & $* *$ & $* *$ & NS & NS & NS \\
\hline No & 60.6 & 13.5 & 3.2 & 27.2 & 54.9 \\
\hline Yes & 68.5 & 19.0 & 4.4 & 26.9 & 49.8 \\
\hline $\begin{array}{l}\text { Difficulty with } \\
\text { number of ADLs } \\
\text { before the COVID- } \\
19 \text { pandemic }\end{array}$ & $* *$ & NS & NS & NS & NS \\
\hline None & 64.7 & 17.0 & 4.0 & 26.7 & 51.8 \\
\hline One & 73.6 & 18.8 & 3.3 & 30.1 & 48.5 \\
\hline Two more & 75.9 & 27.4 & 9.6 & 20.2 & 42.2 \\
\hline $\begin{array}{l}\text { Difficulty with } \\
\text { number of IADLs } \\
\text { before the COVID- } \\
19 \text { pandemic }\end{array}$ & $* *$ & $*$ & $* * *$ & NS & $*$ \\
\hline None & 64.8 & 16.5 & 3.4 & 27.4 & 52.2 \\
\hline One & 74.3 & 23.3 & 5.6 & 26.3 & 45.8 \\
\hline Two more & 76.6 & 24.7 & 10.4 & 23.4 & 42.5 \\
\hline
\end{tabular}

Source: authors' analysis, Understanding Society: COVID-19 Study, 2020. \% applied sampling weight. Number of respondents is 2597. ${ }^{* * *} \mathrm{p}<0.001,{ }^{* *} \mathrm{p}<0.01,{ }^{*} \mathrm{p}<0.05$, NS $\mathrm{p}>0.05$. BESWN means British/English/Scottish/Welsh/Northern Irish (white) 
Table 3. Adjusted odds ratios and confidence intervals about receiving care in the last four weeks and perceived changes in receiving such care since the COVID-19 pandemic

\begin{tabular}{|c|c|c|c|c|c|}
\hline & \multirow{2}{*}{$\begin{array}{l}\text { Receiving care } \\
\text { from outside } \\
\text { the house }\end{array}$} & \multicolumn{4}{|c|}{ Perceived changes in receiving such care } \\
\hline & & $\begin{array}{l}\text { Receiving more help } \\
\text { from some people } \\
\text { who previously } \\
\text { helped }\end{array}$ & $\begin{array}{l}\text { Receiving less help } \\
\text { from some people } \\
\text { who previously } \\
\text { helped }\end{array}$ & $\begin{array}{l}\text { Receiving help from } \\
\text { family, friends or } \\
\text { neighbours who did } \\
\text { not previously help }\end{array}$ & No change \\
\hline \multicolumn{6}{|l|}{ Age group } \\
\hline \multicolumn{6}{|l|}{ 70-74 (ref) } \\
\hline $75-79$ & $\begin{array}{l}1.3 * \\
(1.1 \text { to } 1.6)\end{array}$ & $\begin{array}{l}1.2 \\
(0.9 \text { to } 1.5)\end{array}$ & $\begin{array}{l}0.8 \\
(0.5 \text { to } 1.3)\end{array}$ & $\begin{array}{l}1.1 \\
(0.9 \text { to } 1.3)\end{array}$ & $\begin{array}{l}0.9 \\
(0.8 \text { to } 1.1)\end{array}$ \\
\hline $80+$ & $\begin{array}{l}1.8 * * * \\
(1.4 \text { to } 2.4)\end{array}$ & $\begin{array}{l}1.4^{*} \\
(1.1 \text { to } 1.9)\end{array}$ & $\begin{array}{l}0.8 \\
(0.5 \text { to } 1.4)\end{array}$ & $\begin{array}{l}1.3^{*} \\
(1.1 \text { to } 1.7)\end{array}$ & $\begin{array}{l}0.7^{* *} \\
(0.6 \text { to } 0.9)\end{array}$ \\
\hline \multicolumn{5}{|l|}{ Sex } & Men (ref) \\
\hline Women & $\begin{array}{l}1.2^{*} \\
(1.0 \text { to } 1.4)\end{array}$ & $\begin{array}{l}1.3 * \\
(1.1 \text { to } 1.6)\end{array}$ & $\begin{array}{l}1.1 \\
(0.7 \text { to } 1.7)\end{array}$ & $\begin{array}{l}1.3^{* *} \\
(1.1 \text { to } 1.6)\end{array}$ & $\begin{array}{l}0.6^{* * *} \\
(0.5 \text { to } 0.7)\end{array}$ \\
\hline \multicolumn{6}{|l|}{ Ethnicity } \\
\hline Other ethnic groups & $\begin{array}{l}0.9 \\
(0.7 \text { to } 1.3)\end{array}$ & $\begin{array}{l}0.9 \\
(0.6 \text { to } 1.4)\end{array}$ & $\begin{array}{l}1.3 \\
(0.7 \text { to } 2.7)\end{array}$ & $\begin{array}{l}0.7 \\
(0.5 \text { to } 1.0)\end{array}$ & $\begin{array}{l}1.3 \\
(0.9 \text { to } 1.8)\end{array}$ \\
\hline \multicolumn{6}{|l|}{$\begin{array}{l}\text { Type of household } \\
\text { With an adult or others } \\
\text { (ref) }\end{array}$} \\
\hline Single household & $\begin{array}{l}2.6 * * * \\
(1.9 \text { to } 3.4)\end{array}$ & $\begin{array}{l}1.9 * * * \\
(1.4 \text { to } 2.7)\end{array}$ & $\begin{array}{l}1.2 \\
(0.7 \text { to } 2.2)\end{array}$ & $\begin{array}{l}1.2 \\
(0.9 \text { to } 1.6)\end{array}$ & $\begin{array}{l}0.5^{* * *} \\
(0.4 \text { to } 0.7)\end{array}$ \\
\hline $\begin{array}{l}\text { Only with a partner aged } \\
70+\end{array}$ & $\begin{array}{l}1.7 * * * \\
(1.4 \text { to } 2.2)\end{array}$ & $\begin{array}{l}1.5^{* *} \\
(1.1 \text { to } 2.1)\end{array}$ & $\begin{array}{l}0.7 \\
(0.4 \text { to } 1.2)\end{array}$ & $\begin{array}{l}1.2 \\
(0.9 \text { to } 1.5)\end{array}$ & $\begin{array}{l}0.7 * * \\
(0.6 \text { to } 0.9)\end{array}$ \\
\hline $\begin{array}{l}\text { Only with a partner aged } \\
\text { younger than } 70\end{array}$ & $\begin{array}{l}0.9 \\
(0.7 \text { to } 1.3)\end{array}$ & $\begin{array}{l}1.3 \\
(0.8 \text { to } 2.0)\end{array}$ & $\begin{array}{l}0.6 \\
(0.3 \text { to } 1.4)\end{array}$ & $\begin{array}{l}0.8 \\
(0.6 \text { to } 1.2)\end{array}$ & $\begin{array}{l}0.9 \\
(0.7 \text { to } 1.3)\end{array}$ \\
\hline \multicolumn{2}{|l|}{ Owned outright (ref) } & & & & \\
\hline Owned with mortgage & $\begin{array}{l}0.9 \\
(0.6 \text { to } 1.2)\end{array}$ & $\begin{array}{l}0.7 \\
(0.4 \text { to } 1.2)\end{array}$ & $\begin{array}{l}0.7 \\
(0.3 \text { to } 1.7)\end{array}$ & $\begin{array}{l}0.8 \\
(0.6 \text { to } 1.3)\end{array}$ & $\begin{array}{l}1.2 \\
(0.9 \text { to } 1.7)\end{array}$ \\
\hline Rent & $\begin{array}{l}1.2 \\
(0.9 \text { to } 1.6)\end{array}$ & $\begin{array}{l}0.9 \\
(0.7 \text { to } 1.4)\end{array}$ & $\begin{array}{l}1.5 \\
(0.9 \text { to } 2.7)\end{array}$ & $\begin{array}{l}0.9 \\
(0.7 \text { to } 1.3)\end{array}$ & $\begin{array}{l}0.9 \\
(0.7 \text { to } 1.2)\end{array}$ \\
\hline \multicolumn{6}{|l|}{$\begin{array}{l}\text { Whether had at least } \\
\text { one chronic condition }\end{array}$} \\
\hline Yes & $\begin{array}{l}1.3^{*} \\
(1.0 \text { to } 1.5)\end{array}$ & $\begin{array}{l}1.4^{* *} \\
(1.1 \text { to } 1.9)\end{array}$ & $\begin{array}{l}1.1 \\
(0.6 \text { to } 1.7)\end{array}$ & $\begin{array}{l}0.9 \\
(0.8 \text { to } 1.1)\end{array}$ & $\begin{array}{l}0.8 \\
(0.7 \text { to } 1.0)\end{array}$ \\
\hline \multicolumn{6}{|l|}{$\begin{array}{l}\text { Difficulty with number } \\
\text { of ADLs before the } \\
\text { COVID-19 pandemic } \\
\text { None (ref) }\end{array}$} \\
\hline One & $\begin{array}{l}1.3 \\
(0.9 \text { to } 1.6)\end{array}$ & $\begin{array}{l}0.9 \\
(0.7 \text { to } 1.2)\end{array}$ & $\begin{array}{l}0.8 \\
(0.5 \text { to } 1.5)\end{array}$ & $\begin{array}{l}1.1 \\
(0.9 \text { to } 1.4)\end{array}$ & $\begin{array}{l}1.0 \\
(0.8 \text { to } 1.3)\end{array}$ \\
\hline Two more & $\begin{array}{l}1.4 \\
(0.8 \text { to } 2.5)\end{array}$ & $\begin{array}{l}1.3 \\
(0.7 \text { to } 2.5)\end{array}$ & $\begin{array}{l}1.8 \\
(0.7 \text { to } 4.3)\end{array}$ & $\begin{array}{l}0.6 \\
(0.3 \text { to } 1.2)\end{array}$ & $\begin{array}{l}0.9 \\
(0.5 \text { to } 1.5)\end{array}$ \\
\hline \multicolumn{6}{|l|}{$\begin{array}{l}\text { Difficulty with number } \\
\text { of IADLs before the } \\
\text { COVID-19 pandemic } \\
\text { None (ref) }\end{array}$} \\
\hline One & $\begin{array}{l}1.5^{*} \\
(1.1 \text { to } 2.1)\end{array}$ & $\begin{array}{l}1.5^{*} \\
(1.1 \text { to } 2.1)\end{array}$ & $\begin{array}{l}1.8 \\
(0.9 \text { to } 3.4)\end{array}$ & $\begin{array}{l}1.0 \\
(0.7 \text { to } 1.3)\end{array}$ & $\begin{array}{l}0.8 \\
(0.6 \text { to } 1.0)\end{array}$ \\
\hline Two more & $\begin{array}{l}1.3 \\
\text { (0.9 to } 1.9)\end{array}$ & $\begin{array}{l}1.2 \\
\text { (0.8 to } 1.9)\end{array}$ & $\begin{array}{l}2.8 * * \\
(1.3 \text { to } 5.7)\end{array}$ & $\begin{array}{l}1.0 \\
(0.7 \text { to } 1.5)\end{array}$ & $\begin{array}{l}0.8 \\
(0.5 \text { to } 1.1)\end{array}$ \\
\hline Likelihood Ratio (LR) & 165.03 & 59.78 & 35.43 & 43.76 & 112.32 \\
\hline Chi-Square test & $<0.001$ & $<0.001$ & $<0.01$ & $<0.01$ & $<0.001$ \\
\hline Pseudo R2 & 0.0490 & 0.0255 & 0.04 & 0.0144 & 0.0312 \\
\hline
\end{tabular}

Source: authors' analysis, Understanding Society: COVID-19 Study, 2020. Number of respondents is 2597.

${ }^{* * *} \mathrm{p}<0.001,{ }^{* *} \mathrm{p}<0.01,{ }^{*} \mathrm{p}<0.05$, NS $\mathrm{p}>0.05$. BESWN means British/English/Scottish/Welsh/Northern Irish (white) 
Table A1: Percentage of older people aged 70 plus receiving care in last 4 weeks, by ADLs/IADLs and type of household

\begin{tabular}{|c|c|c|c|c|}
\hline & Single household & $\begin{array}{l}\text { With a partner } \\
\text { aged } 70^{+}\end{array}$ & $\begin{array}{l}\text { With a partner } \\
\text { aged younger } \\
\text { than } 70\end{array}$ & $\begin{array}{l}\text { With an adult or } \\
\text { others }\end{array}$ \\
\hline \multicolumn{5}{|c|}{$\begin{array}{l}\text { Difficulty with } \\
\text { number of ADLs } \\
\text { before the } \\
\text { COVID-19 } \\
\text { pandemic }\end{array}$} \\
\hline None & 77.7 & 67.6 & 51.4 & 51.2 \\
\hline One & 88.2 & 77.8 & 59.4 & 54.4 \\
\hline $\begin{array}{l}\text { Two more } \\
\text { Difficulty } \\
\text { number of } \\
\text { before the } \\
\text { COVID-19 } \\
\text { pandemic }\end{array}$ & 83.3 & 87.0 & 87.5 & 45.5 \\
\hline None & 77.9 & 67.3 & 51.9 & 51.4 \\
\hline One & 94.7 & 75.6 & 64.3 & 57.8 \\
\hline Two more & 94.4 & 88.2 & 69.2 & 44.4 \\
\hline
\end{tabular}

Source: authors’ analysis, Understanding Society: COVID-19 Study, 2020.

Table A2 Percentage of older people aged 70 plus reporting receiving care from different types of non-co-residential carer, by type of household.

\begin{tabular}{llllll}
\hline & $\begin{array}{l}\text { Single } \\
\text { household }\end{array}$ & $\begin{array}{l}\text { With a partner } \\
\text { aged 70+ }\end{array}$ & $\begin{array}{l}\text { With a partner } \\
\text { aged younger } \\
\text { than 70 }\end{array}$ & $\begin{array}{l}\text { With an adult } \\
\text { or others }\end{array}$ & P value \\
\hline $\begin{array}{l}\text { Adult children, } \\
\text { including in-laws }\end{array}$ & 60.6 & 72.3 & 67.2 & 67.5 & $\mathrm{P}<0.01$ \\
$\begin{array}{l}\text { Non co-residential } \\
\text { Spouse or partner }\end{array}$ & 0.3 & 12.6 & 11.2 & 8.3 & $\mathrm{P}<0.001$ \\
$\begin{array}{l}\text { Siblings } \\
\begin{array}{l}\text { Friends } \\
\text { Neighbours }\end{array}\end{array}$ & 8.3 & 8.1 & 7.6 & 6.0 & $\mathrm{P}=0.881$ \\
\hline
\end{tabular}

Source: authors' analysis, Understanding Society: COVID-19 Study, 2020.

Note: sources of care sum to more than $100 \%$ as respondents can report more than one type of care. 